\title{
Prevalence of anticardiolipin antibody in Bangladeshi patients with recurrent pregnancy loss
}

\author{
A.S.M. Giasuddin ${ }^{1}$, Ishrat Mazhar ${ }^{2}$ and A.M. Mujibul Haq ${ }^{3}$ \\ Department of ${ }^{1}$ Biochemistry, ${ }^{2}$ Obstetrics \& Gynecology and ${ }^{3}$ Medicine, Medical \\ College for Women \& Hospital, Uttara Model Town, Dhaka 1230, Bangladesh. \\ e-mail: asmgias@hotmail.com
}

\begin{abstract}
The objective of the present study was to see the prevalence of anticardiolipin antibody (ACA) in Bangladeshi patients (35) with recurrent pregnancy loss. Thirty-seven women with normal pregnancy were included as control. Serum levels $($ mean $\pm \mathrm{SD})$ of ACA $(\mathrm{u} / \mathrm{mL})$ was significantly higher, whereas ANA (Ab-index) and anti-dsDNA (Ab-index) were similar in cases compared to controls (Cases vs Controls $\rightarrow$ ACA: $31.8 \pm 24.3$ vs $10.5 \pm 3.4$, p<0.001; ANA: $1.07 \pm 0.34$ vs $0.92 \pm 0.15$, p $>0.5$; AdsDNA: $0.53 \pm 0.16$ vs $0.52 \pm 0.18, \mathrm{p}>0.5)$. The cases positive for ACA, ANA and anti-dsDNA were $37.1 \%(p<0.001), 20 \%(p>0.05)$ and $2.8 \%(p>0.1)$ respectively. Among the seropositive cases $4 / 35$ $(11.4 \%)$ and $4 / 13(30.8 \%)$ were positive for both ACA and ANA. In controls only 2/37 (5.4\%) and 2/37 (5.4\%) were positive for ACA and ANA respectively and none were positive for both ACA and ANA together simultaneously. Significantly high proportion of cases had O positive blood group $(23 / 35: 65.7 \%, 10 / 13: 76.9 \%)(p<0.01)$. The prevalence of ACA varies according to population being $37.1 \%(13 / 35)$ in our patients with recurrent pregnancy loss and $5.4 \%$ in controls.
\end{abstract}

\section{Introduction}

Antiphospholipid antibody, particularly anticardiolipin antibody (ACA), is associated with a set of striking clinical features known as antiphospholipid syndrome, most notably thrombosis, recurrent pregnancy loss and thrombocytopenia ${ }^{1,2}$. In a study of 65 patients with systemic lupus erythematous, $58 \%$ of those with raised serum antiphospholipid antibody levels had a history of venous thrombosis compared with $16 \%$ of those with normal level ${ }^{2,3}$. Recurrent pregnancy loss, the disease of our interest, is an important feature of the antiphospholipid syndrome. In a large study of the general population, $13 \%$ of women with unexplained recurrent fetal loss were found to have raised serum antiphospholipid antibody ${ }^{4}$. There are also reports of raised antiphospholipid antibody in thrombocytopenia, ${ }^{1,5}$ ACA, antinuclear antibody (ANA) and anti-double stranded DNA antibody (anti-dsDNA) may occur together in antiphospholipid syndrome and systemic lupus erythematosus, although they are separate distinct autoantibodies 5 . However, the prevalence of antiphospholipid antibody in patients with thrombosis, recurrent pregnancy loss and thrombocytopenia varies considerably between reports ${ }^{7,8}$. Moreover, there are only few data on the prevalence of raised antiphospholipid antibody and their clinical associations in the general population ${ }^{8}$. Principally, three types of antiphospholipid antibodies such as antilipoidal antibody, lupus anticoagulant and ACA were discovered in antiphospholipid syndrome ${ }^{8,9}$. Patients with ACA positive had 55\% incidence of early fetal loss, at a time when $3-5 \%$ of normal population have antiphospholipid antibody in low titer ${ }^{9-11}$. In women with normal pregnancy, the incidence of antiphospholipid antibody is very low, as low as $0.2 \%$ for lupus anticoagulant and $2.0 \%$ for $\mathrm{ACA}^{9}$.

In a meta-analysis (25 studies), it was demonstrated that the magnitude of the association between antiphospholipid antibodies and recurrent pregnancy loss varies according to type of antibodies ${ }^{12}$. ACA and ANA may play role in mediating thrombocytopenia in other autoimmune disorders (Sjogren's syndrome, mixed connective tissue disorders, rheumatoid arthritis, systemic sclerosis) and studies evaluating pregnancy out-comes in these patients have yielded conflicting results ${ }^{5,13}$.

The present case-control prospective study was therefore undertaken with the objective to know the prevalence of ACA in recurrent pregnancy loss which may help to initiate anticoagulant therapy, 
e.g. low dose aspirin, or any other relevant anticoagulant, therapy that may result in significant improvement in pregnancy outcome ${ }^{14,15,16}$. ANA and anti-dsDNA were also assayed in serum for probable occurrence of SLE or other autoimmune diseases in our cases ${ }^{5,13}$.

\section{Materials and Methods}

A total of 35 consecutive patients with the history of three or more consecutive early pregnancy loses, i.e. recurrent pregnancy loss and/or unexplained intrauterine death, hypertension during pregnancy, intrauterine growth retardation, diabetes, systemic lupus erythematosus or any other autoimmune diseases or family history of diabetes, systemic lupus erythematosus, other autoimmune diseases, recurrent fetal loss, etc were included in the study'. The diagnosis was made according to clinical criteria and partial thromboplastin time ${ }^{9,17}$. A group of 37 women with normal pregnancy who were para 3 and gravid $4^{\text {th }}$ were also included in the study. After approval by the ethical committee of the MCW\&H, Uttara, Dhaka, the cases and controls were taken from the outpatient department and some private hospitals of Dhaka city. After obtaining consent, proforma was completed and about $5 \mathrm{ml}$ aliquot of blood was taken from each subject. The separated sera were stored frozen at $30 \mathrm{C}$ until analyzed for ACA, ANA and antidsDNA by enzyme immunoassay (EIA) technique using commercially available kits. (ACA: AESKULISA Cardiolipin check, AESKU Diagnostics, Germany, Ref: 3202; ANA: ANA ELISA Kit, LuSys Laboratories Inc, USA, Ref: 5001; dsDNA: DSDNA ELISA Kit, LuSys Laboratories Inc, USA, Ref: 5002). Statistical analyses were made by Z-test, Student's t-test, Chisquared $\left(\chi^{2}\right)$ test and $\mathrm{T}$ calculation using standard equations in calculator manually. The results were reported with $\mathrm{p} \leq 0.05$ as the level of significance accordingly $^{18,19}$.

\section{Results}

Serum levels of ACA, ANA and anti-dsDNA and their statistical analysis by Z-test and Student's ttest are stated in Table I. Mean ACA levels in cases were significantly higher compared to controls $(\mathrm{p}<$ 0.001). Serum mean ANA and anti-dsDNA levels in cases were similar to controls. The statistical analysis by chi-squared $\left(\chi^{2}\right)$ test revealed that significant proportion of cases $(13 / 35,37.1 \%)$ were positive for ACA compared to controls (2/37, $5.4 \%)(p<0.001)$. Distributions for ANA $(p>0.05)$ and anti-dsDNA $(p>0.1)$ were not significant.
Table II shows the distribution of cases and controls according to their serum levels simultaneously positive or negative for ACA and ANA together and their statistical analysis by Chisquared $(\chi 2)$ test. Among the seropositive cases, $4 / 35(11.4 \%)$ and $4 / 13(30.8 \%)$ were positive for both ACA and ANA together. However, Chisquared test revealed that the distribution was not significant $\left(\chi^{2}=1.079, \mathrm{p}>0.1\right)$ and did not indicate high degree of association between ACA and ANA in cases $(T=0.175)$. In controls, only $2 / 37(5.4 \%)$ and $2 / 37$ (5.4\%) were positive for ACA and ANA respectively and none were positive simultaneously for both of ACA and ANA together.

Significantly higher proportion of cases had ' $O$ ' positive blood group (23/35: 65.7\%) and a very high proportion of ACA positive cases had ' $\mathrm{O}$ ' positive blood group (10/13: 76.9\%) (Z-test: $\mathrm{p}<0.001)$. Although high proportion of ANA positive cases had ' $O$ ' positive blood group (3/35, $8.6 \% ; 3 / 7,42.8 \%, \mathrm{p}>0.1)$, the percentage was much lower compared to ACA positive cases and was not significantly different compared to other blood groups $(4 / 35,11.4 \% ; 4 / 7,57.1 \% ; \mathrm{p}>0.1)$.

\section{Discussion}

The persistent presence of antiphospholipid antibodies at medium to high levels is associated with thrombosis, recurrent pregnancy loss and thrombocytopenia. Of the autoantibodies, ACA is most commonly used in clinical practice as one of the criteria for classification of primary antiphospholipid syndrome ${ }^{\mathbf{1 , 2}}$. Serum mean ACA level was significantly elevated in our cases, whereas mean ANA and anti-dsDNA levels were similar to controls $(\mathrm{p}>0.5)$. High proportions of our cases were positive for ACA compared to controls $(p<0.001)$, whereas only $20.0 \%$ and $2.8 \%$ of the cases were positive for ANA $(p>0.05)$ and antidsDNA ( $>0.1)$ respectively. Did these findings mean that most of the cases had primary antiphospholipid syndrome in general? Similar results were reported in another study ${ }^{20}$. Although positivity for ANA did not reach statistical significance, 4 of them were positive for ACA also. Did it mean that some of the cases had one or the other autoimmune disorders complicating the role of ACA in primary antiphospholipid syndrome? Systemic lupus erythematosus or other autoimmune diseases were carefully excluded clinically in any of our cases, although only one case was positive for anti-dsDNA.

Based on a number of in vitro studies, a probable explanation was suggested for the seemingly paradoxical finding that antiphospholipid antibodies 
Table I: Serum levels of ACA, ANA \& A-dsDNA in cases and controls and their statistical analysis*

\begin{tabular}{|c|c|c|c|}
\hline \multirow[b]{2}{*}{ Subject } & \multicolumn{3}{|c|}{ Serum levels of autoantibodies } \\
\hline & $\begin{array}{c}\text { ACA } \\
(\mathrm{u} / \mathrm{mL})\end{array}$ & $\begin{array}{c}\text { ANA } \\
(\mathrm{Ab}-\text { index })\end{array}$ & $\begin{array}{c}\text { Anti-dsDNA } \\
\text { (Ab-index) }\end{array}$ \\
\hline \multicolumn{4}{|l|}{ Cases $(\mathrm{N}=35)$} \\
\hline Observed range & $8.5-70.6$ & $0.56-1.84$ & $0.21-1.11$ \\
\hline Mean $\pm \mathrm{SD}$ & $31.8 \pm 24.3$ & $1.07 \pm 0.34$ & $0.53 \pm 0.16$ \\
\hline $95 \%$ Range & $4.3-102.3$ & $0.35-1.75$ & $0.21-0.85$ \\
\hline $95 \%$ CIM & $23.9-39.7$ & $0.95-1.19$ & $0.48-0.58$ \\
\hline \multicolumn{4}{|l|}{ Controls $(\mathrm{N}=37)$} \\
\hline Observed range & $4.5-30.4$ & $0.61-1.35$ & $0.21-0.88$ \\
\hline Mean $\pm \mathrm{SD}$ & $10.5 \pm 3.4$ & $0.92 \pm 0.15$ & $0.52 \pm 0.18$ \\
\hline $95 \%$ Range & $3.7-17.3$ & $0.62-1.22$ & $0.16-0.88$ \\
\hline $95 \%$ CIM & $9.4-11.6$ & 0.87-0.97 & $0.48-0.57$ \\
\hline Cases vs Controls: & $\begin{array}{c}\text { Z-test } \\
Z=5.145 \\
p<0.001\end{array}$ & $\begin{array}{c}\text { Student's t-test } \\
\mathrm{t}=0.585, \mathrm{df}=70 \\
\mathrm{p}>0.5\end{array}$ & $\begin{array}{c}\text { Student's t-test } \\
\mathrm{T}=0.251, \mathrm{df}=70 \\
\mathrm{p}>0.5\end{array}$ \\
\hline
\end{tabular}

*Cases: Patients with recurrent pregnancy loss; Controls: Women with normal pregnancy; N: Number of subjects; ACA: Anticardiolipin antibody; ANA: Antinuclear antibody; Anti-dsDNA: Anti-dsDNA antibody; Ab-index: Antibody index calculated according to the commercial EIA kits; 95\% Range: Mean \pm 2SD (In case of ACA, antilog of log transformed values); $95 \%$ CIM: $95 \%$ confidence interval of the mean; $p \leq 0.05$ : Significant; $p>0.05$ : Not significant

Table II: Distribution of subjects (cases and controls) according to their serum levels positive or negative for ACA and ANA together and their statistical analysis by Chi-squared $\left(\chi^{2}\right)$ test*

\begin{tabular}{|c|c|c|c|c|c|c|}
\hline & \multicolumn{6}{|c|}{ ACA } \\
\hline & \multicolumn{3}{|c|}{ Cases } & \multicolumn{3}{|c|}{ Controls } \\
\hline & + & - & Total & + & - & Total \\
\hline \multicolumn{7}{|l|}{ ANA } \\
\hline+ & $\begin{array}{r}4(11.4 \%) \\
(30.8 \%)\end{array}$ & 3 & $7(20.0 \%)$ & $0(0.0 \%)$ & 2 & $2(5.4 \%)$ \\
\hline- & $\begin{array}{r}9(25.7 \%) \\
(69.2 \%) \\
\end{array}$ & 19 & 28 & $2(5.4 \%)$ & 33 & 35 \\
\hline Total & $13(37.1 \%)$ & 22 & 35 & $2(5.4 \%)$ & 35 & 37 \\
\hline \multicolumn{2}{|c|}{ Chi-squared $\left(\chi^{2}\right)$ test: } & $\begin{array}{l}\chi 2=2.701, \mathrm{df} \\
\mathrm{T}=0.277(\mathrm{Do} \\
\text { degree of ass } \\
\text { ACA and AN }\end{array}$ & $\begin{array}{l}\text { ate high } \\
\text { ween }\end{array}$ & \multicolumn{3}{|c|}{$\chi^{2}=1.21, \mathrm{df}=1, \mathrm{P}>0.1$} \\
\hline
\end{tabular}

*Cases: Patients with recurrent pregnancy loss; Controls: Women with normal pregnancy; N: Number of subjects; ACA: Anticardiolipin antibody; ANA Antinuclear antibody; $\operatorname{ACA}(+):>17.3 \mathrm{u} / \mathrm{mL} ; \operatorname{ACA}(-): \leq 17.3 \mathrm{u} / \mathrm{mL} ; \operatorname{ANA}(+):>1.22 ; \operatorname{ANA}(-): \leq 1.22 ; \mathrm{T}: \sqrt{ } \chi^{2} / \mathrm{n} ; \mathrm{p} \leq 0.05$ : Significant; $>0.05$ : Not significant

may have an anticoagulant effect in vitro but be associated with thrombosis in vivo ${ }^{8}$. Antiphospholipid antibodies exert an inhibitory action on prostacyclin activity leading to major obstetrical complications and the thrombotic phenomenon along with reduction of prostacyclin is responsible for very high percentage of the pregnancy loss 9 . In patients with recurrent pregnancy loss, there is now good evidence that the episodes of fetal loss are due to placental infarction secondly to thrombosis ${ }^{8,21}$. Moreover the administration of low dose aspirin to patients with recurrent pregnancy loss with antiphospholipid syndrome, which reduces platelet thromboxane A2 production by inhibiting cyclooxygenase, resulted in a significant improvement in fetal outcome ${ }^{14-16,21}$. It is now generally believed that, phospholipidbinding proteins or phospholipid-protein complexes, rather than phospholipids, that constitute the real target of antiphospholipid antibodies $^{22-24}$. Recent studies suggested that antiAnnexin V and anti-prothrombin and anti- $\beta$-Sub 2glycoprotien 1 antibodies may play important role in recurrent pregnancy loss in antiphospholipid syndrome with or without autoimmune disorders.
Thus, the possibility exist that ACA negative cases in our study may have other autoantibodies as noted above ${ }^{22-26}$.

Another interesting finding in the present study was that 23 cases had ' $\mathrm{O}$ ' positive blood group of which 10 patients were ACA positive, while only 3 patients were ANA positive $(p<0.001)$. Did these results mean that associations exist between serum ACA level and ' $\mathrm{O}$ ' positive blood group in our cases? Literature survey could not reveal much towards answering this question. However, one study reported non association of $\mathrm{ABO}$ blood groups with diabetes mellitus in Bangladesh ${ }^{27}$. Another study showed association of ABO blood groups with malignancies for some of the organs and tissues ${ }^{28}$. Since our results were statistically highly significant, explanations through further studies must be found regarding the probable role of $\mathrm{ABO}$ blood groups in recurrent pregnancy loss.

In conclusion, the prevalence of ACA in recurrent pregnancy loss varies according to population being $37.1 \%$ in our cases. In women with normal pregnancy the prevalence of ACA is usually very low being $5.4 \%$. 


\section{Acknowledgements}

The authors acknowledge The Medical \& Health Welfare Trust, Bangladesh for the financial support, Mr. M.H. Khan, Biochemist for technical assistance and Mr. Moniruzzaman Khan, Assistant Programmer, for internet browsing and composing the manuscript.

\section{References}

1. Harris EN, Gharavi AE, Hughes GRV. Antiphospholipid antibodies. Clin Rheum Dis. 1985; 11: 591-609.

2. Asherson RA. A 'primary' antiphospholipid syndrome? J Rheumatol. 1988; 15: 1742-46.

3. Harris EN, Gharavi AE, Boey ML, Patel BM, Mackworth-Young CC, Loizou S, Hughes GRV. Anticardiolipin antibodies: Detection by radioimmunoassay and association with thrombosis in SLE. Lancet 1983; ii: 1211-14.

4. Al-Daqal S, Mansouri M, Qari MH, Sibiany A. Recurrent intestinal perforations as a presentation of antiphospholipid syndrome. Ann Saudi Med. 2006; 26: $52-55$.

5. Cowchock S, Smith JB, Gocial B. Antibodies to phospholipids and nuclear antigens in patients with repeated abortions. Am J Obstet Gynaecol. 1986; 155: 1002-10.

6. Chapel H, Haeney M, Misbah S, Snowden N. Essentials of clinical immunology. $4^{\text {th }}$ ed. Oxford, Blackwell Science, 1999, pp 183, 282-94.

7. Harris EN, Gharavi AE, Patel SP, Hughes GRV. Evaluation of the anticardiolipin antibody test: Report of an international workshop held $4^{\text {th }}$ April 1986. Clin Exp Immunol. 1987; 68: 215-22.

8. Mackworth-Young C. Antiphospholipid antibodies: More than just a disease marker. Immunol Today 1990; 11: 60-65.

9. Dasgupta S. Immunologically complicated pregnancy. In: Pregnancy at risk: Current concepts. Krisna U, Tank DK, Daffary S (eds). $4^{\text {th }}$ ed. New Delhi, Jaypee Brothers, 2001, pp 194-99.

10. Kuttech WH, Carr BR. Recurrent pregnancy loss. In: Textbook of reproductive medicine. Carr BR, Blackwell RC (eds). Norwalk, Apple-Ton and Lange, 1992.

11. Lockwood CJ, Romero R, Feinberg RF, Clyne LP, Coster B, Hobbins JC. The prevalence and biologic significance of lupus anticoagulant and anticardiolipin antibodies in a general obstetric population. Am J Obstet Gynecol. 1989; 161: 369-73.

12. Opatrny L, David M, Kahn SR, Shrier I, Rey E. Association between antiphospholipid antibodies and recurrent fetal loss in women without autoimmune disease: A meta-analysis. J Rheumatol. 2006; 33: 2214-21.

13. Chung L, Flyckt RLR, Colon I, Shah AA, Druzin M, Chakravarty EF. Outcome of pregnancies complicated by systemic sclerosis and mixed connective tissue disease. Lupus 2006; 15: 595-99.
14. Rai R, Cohen H, Dave M, Regan L. Randomized controlled trial of aspirin and aspirin plus heparin in pregnant woman with recurrent miscarriage associated with phospholipid antibodies (or antiphospholipid antibodies). BMJ 1997; 314: 253-57.

15. Kutteh WH. Antiphospholipid antibody-associated recurrent pregnancy loss: Treatment with heparin and low dose aspirin is superior to low-dose aspirin alone. Am J Obstet Gynecol. 1996; 174: 1584-89.

16. Uzan S. Aspirin and prevention of vascular complications: There are still indications. Ultrasound Obstet Gynaecol. 2000; 15: 4-6.

17. Greaves M, Cohen H, Machin SJ, Mackie I. Guidelines on the investigation and management of the antiphospholipid syndrome. Br J Haematol. 2000; 109: 704-15.

18. Kirkwood BR, Sterne JAC. Essential medical statistics. $2^{\text {nd }}$ ed. Oxford, Blackwell Science, 2008.

19. Prabhkara GN, Biostatistics. $1^{\text {st }}$ ed. Jaypee, New Delhi, 2008.

20. Khan A, Tayyib M, Tasneem T, Farooq M, Rehman F, Ujjan ID. Serum anticardiolipin antibodies in recurrent abortion. Ann King Edward Med Coll. 2004; 10: 40607 .

21. Elder MG, De Swiet M, Robertson A, Elder MA, Flloyd E, Hawkins DF. Low dose aspirin in pregnancy. Lancet 1988; 1(8582): 410.

22. Nicola B, Elio T, Danito V, Marilina T, Renato $T$. Prevalence and clinical correlation of antiphospholipid-binding protein antibodies in anticardiolipin-negative patients with systemic lupus erythematosus and women with unexplained recurrent miscarriages. Arch Pathol Lab Med. 2005; 129: 61-68.

23. Wilson WA, Gharavi AE, Koike T, Lockshin MD, Branch DW, Piette JC, Brey R, Derksen R, Harris EN, Hughes GR, Triplett DA, Khamashta MA. International consensus statement on preliminary classification criteria for definite antiphospholipid syndrome: report of an international workshop. Arthritis Rheum. 1999; 42: 1309-11.

24. Amengual O, Atsumi T, Koike T. Specificities, properties, and clinical significance of antiprothrombin antibodies. Arthritis Rheum. 2003; 48: 886-95.

25. Wang $\mathrm{X}$, Campos $\mathrm{B}$, Kaetzel MA, Dedman JR. Annexin $\mathrm{V}$ is critical in the maintenance of murine placental integrity. Am J Obstet Gynecol. 1999; 180: 1008-16.

26. Arnold J, Holems Z, Pickering W, Farmer C, Regan L, Cohen H. Anti-beta, glycoprotein 1 and antiannexin V antibodies in women with recurrent miscarriage. $\mathrm{Br} \mathrm{J}$ Haematol. 2001; 113: 911-14.

27. Rahman M. Non-association of ABO blood groups with diabetes mellitus in Bangladesh. Bangladesh Med Res Counc Bull. 1976; ii: 144-46.

28. Afrose S. Association of $\mathrm{ABO}$ blood group with malignancies. J Bangladesh Coll Phys Surg. 2005; 23: $18-24$. 